Erika Prijatelj

University of Ljubljana, Slovenia

\title{
Solidarity from the Point of View of European Catholic Experts
}

\author{
Report on the international conference on the topic of solidarity under \\ the auspices of the Department of Applied and Pastoral Theology at the \\ Faculty of Theology the University of Ljubljana on 13 April 2011
}

\section{Introduction}

In n. 38 of Sollicitudo Rei Socialis Pope John Paul II calls solidarity a virtue for the first time. Previously in his speeches and writtings he had referred to solidarity as an attitude, duty or principle. Thanks to the Pope in 1987 the Church articulated a new concept of social teaching where it looks at the power of virtue and the power of solidarity as virtues capable of tearing down unjust structrues that hold millions in poverty and abuse, and build up structures of virtue that will form us into one human family.

Solidarity is key to an understanding of John Paul II's thought on social questions. The innovative dimensions of the Pope's teaching were an inspiration for the international conference on the topic of solidarity under the auspices of the Department of Applied and Pastoral Theology at the Faculty of Theology in Ljubljana in Slovenia on 13 April 2011. Nineteen international experts in the field from Austria, Poland, Switzerland, Serbia and Slovenia lectured on this topic. In this paper we are going to present some of their reflections and draw some inferences from them.

\section{Sociological reflection on solidarity}

\subsection{Boundaries and social injustice in Europe}

Among the lecturers were especially welcomed two guests from Poland: Associate Professor Dr. Elzbieta Osewska and Professor Dr. Josef Stala with 
a presentation on Solidarity as overcoming boundaries in Europe. They drew attention to the concept of "solidarity" which was developed initially among the socialists by P. Lerou in opposition to the Christian idea of love, as the effective response to social problems. Since then the concept of solidarity has been slowly transformed and Christianized. The well-known Polish example (workers in the shipyard, who started the social movement "Solidarity") brings new perspectives. "Solidarity" in this context signifies people who accept responsibility for one another. There is also an understanding of "solidarity" connected with the present situation in Europe. Confrontation with historical (interiorized) boundaries is an ongoing challenge for Europe. This problem cannot be overcome by means of treaties or legal agreements. The problem lies in people's mental boundaries and intensive work is needed among us all in order to establish the psychological and spiritual mindset for integrating the concerns of all Europeans. The boundaries we face are territorial, historical, cultural, religious, linguistic, economic, political, ideological, legal, sociological, psychological, educational and communicative. In this context, a Christian understanding of solidarity means overcoming various boundaries, especially the mental ones.

Assistant Professor Dr. Igor Bahovec clearly pointed out a global sociological reflection with the title Social injustice and lack of solidarity. He explained that different forms of social inequalities exist in all societies, even in societies with a high degree of solidarity. The problem that many contemporary societies have been facing is an enormous increase in inequality due to the loss of a sense of solidarity. Why this loss? Two main obstacles to solidarity are »not giving « and »not accepting «; these seem to be expressed in broader social forms as immoderate self-sufficiency, independence, insensitivity to others, and indifference. It is the view of the author that the problem is deeper, and would be better expressed by the hypothesis that we are living in a society of indifference. It is not enough to work on interpersonal relationships to find a genuine answer to the lack of solidarity, because the other who needs solidarity is often a distant other. Solidarity is a form of active relationship both to members of our own communities and societies, and to others »outside« them. Activities of this type require action in three dimensions at the same time: it is vital to strengthen interpersonal solidarity, to foster development of a culture of solidarity and to strive to strengthen solidarity aspects of social institutions. It is not enough to demand state regulations to help people in need - such a stance is a denial of true and genuine solidarity: to be a better person means showing more solidarity.

In addition to this reflection doctoral candidate Mojca Resnik accentuated that in Europe today, social inequality is mostly seen in the form of income inequality. 
Individuals with a higher income possess more power and influence in our society. Despite efforts to reduce social inequality in Europe with the help of education (the concept of inclusive education) and measures to increase intergenerational solidarity, there are many factors of globalization, such as economic migration, which will have a negative impact on the progress of European societies in the years to come.

\subsection{Poverty and hunger}

An interesting speech on Let's Break Bread Together was delivered by Associate Professor Dr. Marjan Simčič. He declared that no one really knows how many people are undernourished. The statistic most frequently cited is that of the United Nations Food and Agriculture Organization (FAO), which measures 'under nutrition'. The most recent estimate, released in October 2010 by FAO, says that 925 million people are undernourished (13.1 percent, or 1 in 7 people are hungry). It has been argued that the FAO approach is not sufficient to give accurate estimates of malnutrition. Poverty is the principal cause of hunger. The causes of poverty include the lack of resources of the poor, an extremely unequal income distribution in the world and within individual countries, conflict, and famine itself. Demographic considerations alone cannot explain the poor distribution of food resources. These facts call for a change of attitude and habits with regard to life-styles and the relationship between resources and goods, as well as for an increased awareness of one's neighbour and his or her legitimate needs. The human race is sufficiently inventive to modify situations and respond to increasing needs. Education provided for everyone, equipment adapted to local situations, wise agricultural policies and equitable economic networks can be so many factors which will produce positive effects in the long run. The world produces enough food to feed everyone. World agriculture produces $17 \%$ more calories per person today than it did 30 years ago, despite a $70 \%$ population increase. This is enough to provide everyone in the world with at least $2,720 \mathrm{kcal}$ per person per day. Harmful economic systems are the principal cause of poverty and hunger.

\subsection{Social Doctrine of the Catholic Church}

Solidarity in the Social Doctrine of the Catholic Church was presented by Assistant Professor Dr. Tadej Stegu. Starting with Pius XII, the term solidarity is used ever more frequently and with ever broader meaning in the context of the Church's social teaching by the Magisterium: meanings range from that of "law" in the same encyclical to that of "principle", "duty", "value", and finally on the 
initiative of John Paul II that of "virtue". The Compendium of the Social Doctrine of the Church stresses that Solidarity highlights in a particular way the intrinsic social nature of the human person, the equality of all in dignity and rights and the common path of individuals and peoples towards an ever more committed unity. Solidarity is also an authentic moral virtue, not a feeling of vague compassion or shallow distress at the misfortunes of so many people, both near and far. The catechism of the Catholic Church is concrete: solidarity is manifested in the first place by the distribution of goods and remuneration for work. As a culmination and example of the solidarity, the Church's social doctrine, it points to nothing else and nothing less than the life of Jesus of Nazareth, the New Man, who is one with humanity even to the point of "death on a cross" (Phil 2:8). In him it is always possible to recognize the living sign of that measureless and transcendent love of God-with-us, who takes on the infirmities of his people, walks with them, saves them and makes them one.

\section{Educational reflections on solidarity}

\subsection{Solidarity in schools and the university}

Solidarity means an integrated effort to create a healthy and fair society. It expresses a willingness to help and collaborate with each other and is the first step in a serious approach to a better, fairer world. That is why each individual is invited to show more solidarity everywhere - in the family, at work, in wider social circles, and also among youngsters at school.

Competition rules in the classroom: students compete for better results at exams, for better results at sports etc. But on the other hand there are students who only go to school to be in the "good company « of their schoolmates, they often skip classes and then they call for »solidarity « along the lines: »Let's all fail the exam so we repeat it!« They can gather one third of their schoolmates, who support them in their intention and they succeed in re-taking the test. Excellent students belittle the ones that do not care about school, and the ones that do not care belittle the »nerds «. Is there any possibility of solidarity between them? However they do know that solidarity is a value much needed and expected nowadays.

In the same manner playing is not supposed to be just a random spending of free time, but is supposed to stimulate one's mental capabilities, thus enabling transcendence of the body's limitations. Through this pattern, a new possibility of creative play is opened, which goes beyond the boundaries established 
by our culture. Today the young in western society soon meet the world of consumerism, which works on the principle of exceeding an individual's needs. On the other hand, according to Assistant Professor Dr. Janez Vodičar adolescents are not blind to the problems of the modern world. They are deeply touched by unfairness and poverty. Thus, education has to be formed in a way that enables these young people to shape their thoughts, through believing that it makes sense to do something, and that it is possible to overcome the enticement of a single moment of pleasure. Especially since the path to God always leads through caring for our neighbor, and through breaking out of an entanglement in the 'here and now'.

Ljubljana University is attended by almost 50,000 students, and some of them are facing different difficulties while studying. Regarding the level of bureaucracy solidarity can be divided into three types: a) solidarity between friends and class-mates, b) organized solidarity among students (student tutoring) and c) formal solidarity from student organizations. The first is the most developed when students help each other out of friendship. From this kind of solidarity was developed student tutoring, when senior students are helping junior students, which has developed into a more institutionalized form of help. The third form of solidarity is the »Študentski tolar « foundation, which is part of the Student Organization of the University of Ljubljana; this helps students in financial difficulties with one-time financial help. While the first two types of solidarity are based on individual member schools of the university, the third is meant for all students at the university.

\subsection{Empathy, aesthetic and stimulation of (non)solidarity in movies}

We receive information from different sources, which is then passed through the thalamus to other centers in the brain in which we internalize and process the data received. Finally (partially) processed information remains in the amygdala, which acts as a kind of "storehouse" for emotional experiences while also coordinating our reactions. From here information travels around the body, triggering various chemical processes and changing how we feel. The key role in empathy is played by mirror neurons, which react to information as if they themselves were in the situation in which they see others. This is what happens, for example, when we are with someone who is apparently very ill. When we are with them it is often they who create a cheerful atmosphere. Thus we have become familiar with their illness and "taught" our body about it. They have also sensed our concern. In fact, we have partly exchanged roles. Communication and emotions are repeatedly harmonized, while at the same time we have shared 
some of the pain of the one who is ill, while they have shared our concern. In spite of the pain which we have shared through empathy, together we have helped to make life better. According to Associate Professor Dr. Stanko Gerjolj, Dean of the Faculty of Theology in Ljubljana, empathy, requires communication - especially in the educational process. Experience on its own is not enough, because what we are feeling has to be shared.

In this context in the light of catchy marketing phrases such as, "I never share", "Stingy is cool" Professor Dr. Franz Feiner from Austria asks: Where is a society going which postulates such an attitude and offers such a role-model? How can school and religion class counteract withdrawal of solidarity? To achieve this it is necessary to have the following aims: Within the meaning of aesthetic religious pedagogy (aisthanestai) learning to sense one's own needs and the needs of others, and consequently rediscovering the connection between aesthetic and ethic.

Important content: self-perception as a basis for the perception of others; prophets as an impulse, to become sensitive to injustice in class and to have the courage to stand up for one's beliefs and actions; to move from one's own little world to "global" thinking and action, to a "planetary awareness" and a "planetary spirituality". Suitable methods: learning to act ethically through roleplay; developing ethical imagination and creativity through conflict stories and learning to act independently in projects. Acting independently, on one's own initiative, should be learned out of the experience of being loved.

The value of solidarity rarely appears on a screen, since in the world of Hollywood movie production destructive values of violence and egoism tend to predominate. For that reason, the movies which stimulate positive values have so much greater educational value for both younger and older audiences. In accordance with doctoral candidate Andraž Arko, positive representation of movie characters, who act in a spirit of solidarity or convert from stubborn selfishness and egoism to solidarity and altruism, stimulate a viewer on a cognitive and especially on the emotional level to imitate that behavior. That kind of movie offers great potential in educational work with children (for instance Cars, Over the Hedge, Horton etc.), youth and also with adults (for instance Pay It Forward, Robin Hood: Prince of Thieves, Gran Torino, Mother Theresa etc.) in the context of group meetings, spiritual retreats, discussion groups etc. Of course, we need to evaluate the film properly in the context of analysis and discussion following screening. That kind of cognitive and emotional awareness of the content and actions of states and impressions that the movie arouses in the viewer, can strongly stimulate decisions to participate in the field of solidarity. 


\section{Formation for solidarity in the life of seminarians}

\subsection{Christological and ecclesiological dimension}

In the seminaries formation has to be directed towards the goal to become real shepherds of souls, according to the example of our Lord Jesus Christ, teacher, priest and shepherd. They should be prepared for the Service of the Word; for the Service of Worship and Consecration; for the Service of the Shepherd so that they will be able to make present Christ, for even the Son of Man did not come to be served, but to serve, and to give his life as a ransom for many (Mk 10:45), that they might win more of them when they have made themselves servants to all (cf. 1Cor 9:19).

God is solidarity with us and sends his Son to save us so that whoever believes in him should not perish but have eternal life. In this solidarity the priest is called, both to receive a gift and to place himself at God's disposal; so that God, with the priest's collaboration, continues the work of salvation. In this connection, the priest is called to realize the example of Jesus who »did not come to be served, but to serve, and to give his life as a ransom for many« (Mk 10:45). Jesus saw the crowd and felt compassion for it (cf. Mt 15:32); Jesus said to the apostles, »You give them something to eat « ( $\operatorname{Lk} 9: 13)$ !

The instruction to the disciples and through them also to priests, »Do this in memory of me « ( $\operatorname{lk} 22: 19)$, does not refer only to the celebration of the Eucharist, but also to Jesus' example of self-sacrifice and salvation. The apostles, bishops and priests continue Jesus' work: they model themselves on Jesus Christ. A priest puts himself at the disposal of the church, in order to enter into the service of the Church: proclamation, liturgy and charity. This is the greatest service, putting oneself in this work with the purpose of bringing people the greatest fruits that exist: the Word of Life, the Eucharist and life in a fraternal community. Seminarians enter the way which leads them into service and self-donation. This is a great sense of solidarity, which embraces the whole perspective of the seminarian's life.

Thoughts on the solidarity of the priestly vocation can be found in the decrees of the Council and in many ecclesiastical documents. For example: the Decree on Priestly Training (Optatam totius), the Decree on the Ministry and Life of Priests (Presbyterium ordinis), I Will Give You Shepherds (Pastores dabo vobis)...

\subsection{The seminarians' solidarity in the Theological Seminary in Ljubljana}

A theological seminary is a time and place where the seminarians called to the priesthood already live their vocation to a certain extent. The seminarians within 
their community, which means very concrete people and relations, collaborate in the mutual formation of life in a community and the development of their vocation. In this time and place, the seminarians experience and form themselves in solidarity with other seminarians. It is about helping brothers that are in trouble; it is about solidarity in relations and in small things as well. The seminarians experience solidarity in shouldering responsibility and realizing certain common services divided among the seminarians themselves. These services are necessary for the common living in the house; and for the collaboration in liturgy and work that the seminary has as a whole, in relation to the diocese and the Church in Slovenia.

In the time of the seminary, solidarity plays an important role in the mutual sharing of spiritual goods: common prayer, individual prayer and mutual help, exchange of spiritual experiences. The seminarians are regularly encouraged and invited, through personal addresses and meetings, to get to know God's will and to form themselves by the example of Jesus Christ, with the help of God's Word. Thus they are constantly formed from the outside and they gain inner experience with a personal sharing.

The next field of solidarity can be found in the seminarians' study, at the Faculty of Theology as well as in their personal studies. Their program contains lectures and literature about solidarity and the social doctrine of the Church. Beside the regular studies, the seminarians are often invited to lectures and meetings with persons who live solidarity and give testimonies on it.

\subsection{The seminarians' solidarity in their relation with the people with whom they are connected}

The closest people that participate in the solidarity of the seminarians are certainly the members of their own families. There they gained their first experience of solidarity; when they come back home, they can testify and live solidarity towards the family in a new way. This aspect is very important.

The other group of people with which the seminarians come in contact, regarding solidarity - in the field of human relations as well as ecclesiastical aspects - are the believers from their home parish. In this spirit, they meet with their parish priest, with parochial collaborators, with other parishioners and with all the people of their place. The seminarians can live their solidarity in the life of the parish also in other parishes, which represent new challenges to them. These are the parishes where they are sent to for pastoral practice. They reflect upon this edifying experience with the parish priests about their life and service. 
In a similar way, as they meet with the brothers in the seminary, they also meet with their schoolmates at the Faculty of Theology. Here the seminarians are specially connected in the process of study and in collaboration within the academic field. In this area the occasions for testing somebody's own endeavor for service in the world show frequently towards the different and towards those who think differently.

At the beginning of the year, in the seminary, each of the seminarians was invited to choose some charity to which he would dedicate a certain period of time every week. This initiative was accepted and it has been very well realized.

What else should be done and what do we have to improve? According to Dr. Franci Šuštar, rector of the seminarians in Ljubljana, the tasks are numerous. It is necessary to overcome self-sufficiency, individualism and insensitivity. $\mathrm{He}$ proposes three initiatives:

a) Profound empathy with a person;

b) Personal endeavor in achieving and working for justice and truth;

c) Qualifications to enter the social field with the social doctrine and a sense of solidarity.

In the field of solidarity there are always great expectations. We can never be satisfied with what we have achieved. Christ's love urges us to look for new ways and possibilities. The Church is called to this, especially priests and seminarians.

\section{Ecumenical solidarity}

\subsection{Bearing with one another in faith}

Theology today is pluralistic, confessionalist and ecumenical. Ecumenism is the theology of the 21st century and the key to church renewal. The acceleration of globalization and secularization today demands that today's Christians cooperatively - rather than competitively - work out answers to help modern men and women. Although a lot is already being done in this field, we observe that alienation and prejudice from more polemic eras still form barriers, that brothers and sisters of different faiths do not recognize the equal partners which they need for dialogue. This does not mean that we have to allow theology to evaporate into abstract and non-confessional neutrality, but that we need to look in depth at existing church tradition, so that theology will remain purely confessional.

Particularly burning issues which face the Church in our times are: bioethical questions, which call us to respect and defend human life; the process of 
European union which is challenging the Church to discover and develop new forms of solidarity; and understanding religiousness as an important sociological phenomenon within which Christianity has to find its place. NELCEE, in the framework of the World Council of Churches has contributed to the development of approaches to religious education and formation in Central and Eastern Europe.

\subsection{The Ecumenical Movement in Slovenia}

In Slovenia ecumenical thinking and practice have been present since the time of the 2nd Vatican Council from which it derives its principles and incentive. The Roman Catholic, Serbian Orthodox, Evangelical and Pentecostal churches are those most closely connected with ecumenism. Underlying this is the so called »spiritual ecumenism«, which is expressed in shared prayer and worship, particularly in the form of the annual Octave of Prayer for Christian Unity from 18-25th January. Such common worship is carried out principally in cities in which Dioceses have their seat.

In the north-eastern region of Slovenia, which is the home of the greatest number of Evangelicals, inter-church marriages and baptisms are also practiced in the presence of Catholic and Evangelical priests. During the summer »Ecumenical dialogues « attended by young people and hosted by Evangelical parishes in Prekmurje help people to get to know each other.

The Slovene Ecumenical Council, which has existed since 1965, publishes a selection of Ecumenical papers contributed mainly by Catholics and Evangelicals, with occasional Pentecostal contributions. In 1993 the Slovene Bible Society was founded and has been very successful and includes not only the churches already named but also the Union of Baptist Churches and the Christ's Church of Brothers. In 1997 the Bible Society published an entirely new and complete translation of the Holy Scriptures, which was a milestone in the history of the spread of the Sacred Scriptures in Slovenia. They also publish a number of other study aids.

Another significant actor in the ecumenical field is the Faculty of Theology in Ljubljana and its annex in Maribor. In its educational and research activities it fosters an ecumenical spirit and it also publishes articles and books about dialogue. Their students include a few members of other denominations, mostly Pentecostal and Evangelical Christians. Some of these have already been awarded masters degrees or doctorates. Moreover, the Faculty of Theology in Ljubljana made a cooperative agreement with the Evangelical Faculty of Theology in Osijek in Croatia a few years ago; this collaboration takes place at student and teaching levels, with collaboration on symposia and publications. 
The Council of Christian Churches in Slovenia was founded in 1994 as a working body for the above-mentioned churches. This Council collaborated in the preparation of the new Act on Freedom of Religion and speaks in public from time to time to state our common stance on important social and moral issues. The State is in favor of ecumenical cooperation: the pastoral service for military personnel includes both Catholic and Evangelical priests. One of the objectives of the Council of Christian Churches is to have Good Friday declared a national holiday and a non-working day.

There is also solidarity and collaboration in the media: thus members and clergy of different churches work together on national and local radio and television. And finally it's important to mention the ecumenical solidarity in the field of social and humanitarian work. It is true that each church has its own humanitarian organizations, but their work crosses church boundaries and help is not dependent on church membership but on social need.

\section{Conclusion}

The root of solidarity is in what generates human co-responsibility, makes coresponsibility an ethical imperative, and makes the exercises of co-responsibility something good, fulfilling, and salvific. The role of the church in setting this solidarity in motion has been twofold. First, in a more instrumental way, the church has played a positive role in helping others come to know the truth of the poor majority. The Church has been an instrument for giving voice to the cry of the poor. We hope that in this respect our international conference with its reflections and open questions has also contributed. Secondly, to the extent that the Church has itself become a Church of the poor, it has become a real symbol of the poor, not only pointing to their truth from outside, but expressing that truth within itself, for example in the field of education and formation on different levels.

The Church's turn toward the poor, giving the word its broadest meaning, whether in the universal Church or in a particular local Church, it is the basic solidarity of the Church, that with which it carries out its mission and maintains its identity. Moreover, it is the basic solidarity that begins to dissolve the isolation of local Churches and establish new, positive relationships among local churches. On the basis of this fact we can also understand the fresh ecumenical movement which means that the different Christian confessions relate to one another today. The issue it deals with is how the different "universal" Churches, composed of 
local Churches, should be related. In the past years, there has been a change, in both theory and practice, in the understanding of what these relationships should be and what purpose they serve.

The practice of solidarity with its dimensions of empathy, compassion, reconciliation, justice, collaboration and formation can transform individuals and society. As a principle, attitude, or duty it operates in one particular fashion, calling forth certain values and actions. As a virtue it has a power that goes far beyond its effectiveness as an attitude, principle or duty. Virtue has the power not only to transform us, but moves us toward the good and makes us good.

With great insight John Paul II rightly called solidarity a virtue. He saw the moral crisis of our world and he had the wisdom to name the solution. Solidarity as a virtue has the potential to educate us for a new historical period where equality is mutual, interdependence is informed by solidarity, and the common good is enhanced with peace. Empathy, mercy and love move solidarity into action and help sustain the disposition. 